\title{
Dynamic Effects of Acid on Barrett's Esophagus An Ex Vivo Proliferation and Differentiation Model
}

\author{
R.C. Fitzgerald, M.B. Omary, and G. Triadafilopoulos \\ Gastroenterology Section, Palo Alto Veterans Affairs Health Care System, Palo Alto, California 94304, and Stanford University \\ Gastroenterology Division, Stanford, California 94305
}

\begin{abstract}
Barrett's esophagus (BE), or specialized intestinal metaplasia, is a premalignant heterogeneous epithelium associated with reflux and an increased risk for adenocarcinoma. Since acid is a major component of refluxate, we investigated its effects ex vivo on cell differentiation as determined by villin expression; and on cell proliferation, as determined by tritiated thymidine incorporation and proliferating cell nuclear antigen expression. To mimic known physiological conditions, endoscopic biopsies of normal esophagus, BE, and duodenum were exposed, in organ culture, to acidified media ( $\mathrm{pH} 3-5)$ either continuously, or as a 1-h pulse and compared with exposure to $\mathrm{pH} 7.4$ for up to $24 \mathrm{~h}$. Before culture, villin expression was noted in $25 \%$ of BE samples, and increased after 6 or $24 \mathrm{~h}$ of continuous acid to $50 \%$ or $83 \%$ of BE samples, respectively. Increased villin expression correlated with ultrastructural maturation of the brush border. In contrast, an acid-pulse followed by culture at $\mathrm{pH} 7.4$, did not alter villin expression in BE. Moreover, continuous acid exposure blocked cell proliferation in BE, whereas, an acidpulse enhanced cell proliferation, as compared to $\mathrm{pH}$ 7.4. Based on our ex vivo findings, we propose a model in which the diverse patterns of acid exposure in vivo may contribute to the observed heterogeneity and unpredictable progression to neoplasia of BE. (J. Clin. Invest. 1996:2120-2128.) Key words: intestinal metaplasia • gastroesophageal reflux • villin $•$ brush border
\end{abstract}

\section{Introduction}

Barrett's esophagus $(\mathrm{BE})^{1}$ is a commonly noted condition in humans, whereby normal squamous esophageal epithelium becomes replaced by metaplastic intestine-like epithelium containing goblet cells (1-5). This specialized intestinal metaplasia is noted in $\sim 10 \%$ of patients suffering from gastroesophageal reflux disease and is associated with nearly a 30 -fold increased

Address correspondence to G. Triadafilopoulos, M.D., Chief, Gastroenterology Section $(111 \mathrm{G})$, Veterans Affairs and Health Care System, 3801 Miranda Avenue, Palo Alto, CA 94304. Phone: 415-4935000 x64498; FAX: 415-852-3259.

Received for publication 16 May 1996 and accepted in revised form 23 August 1996.

1. Abbreviations used in this paper: $\mathrm{BE}$, Barrett's esophagus; LDH, lactate dehydrogenase; PCNA, proliferating cell nuclear antigen.

J. Clin. Invest.

(C) The American Society for Clinical Investigation, Inc. 0021-9738/96/11/2120/09 \$2.00

Volume 98, Number 9, November 1996, 2120-2128 risk for the development of adenocarcinoma of the esophagus and gastric cardia $(6,7)$. These cancers, which were previously considered rare, have increased in incidence by $74 \%$ over the past two decades, a rate exceeding that of any other cancer (7). Adenocarcinoma in BE does not arise de novo but is thought to follow a multistep process in which the metaplastic epithelium sequentially develops low-grade dysplasia, high-grade dysplasia, early adenocarcinoma, and eventually invasive cancer (8).

Epidemiological evidence suggests that patients with $\mathrm{BE}$ have greater exposure times to gastric acid than patients with esophagitis or normal controls, suggesting a significant role for acid reflux in the development and subsequent malignant progression of BE (9-11). However, there is little direct evidence for such a role of acid in $\mathrm{BE}(12,13)$, and the mechanism(s) by which acid reflux might affect the neoplastic progression of $\mathrm{BE}$ are not understood (5). Furthermore, acid suppressive therapy has not yet been proven to be effective in the treatment of BE, nor in the prevention of adenocarcinoma (14-16).

Factors responsible for the multistep neoplastic progression of cancer would be expected to variously affect Barrett's epithelium given its heterogeneous nature. For any given patient, $\mathrm{BE}$ is heterogeneous on many levels: histopathologically in terms of the degree of dysplasia and adenocarcinoma, on a cellular level in terms of cell differentiation $(17,18)$, and at a molecular level as noted for differences in activation of the src oncogene (19) and DNA content (3). This heterogeneity has far reaching implications in terms of cancer surveillance for these patients. Multiple serial biopsies must be taken in order to screen for potential areas of dysplasia or carcinoma and even with this approach it is possible to miss a small, focal area of severe dysplasia or adenocarcinoma (20). To add to the complexity of BE, even in the absence of dysplasia, different areas of $\mathrm{BE}$ from a given patient exhibit variable degrees of differentiation as manifested by variability in the expression of the microvillus actin binding protein villin (18), or variability in src tyrosine kinase specific activity (19). The pattern of reflux disease, and hence acid exposure of $\mathrm{BE}$, is also very heterogeneous. For example, reflux events are influenced by posture (21), have a circadian pattern and the amount of reflux that occurs in any one individual varies from day to day (22). Furthermore a reflux event may be rapidly cleared or prolonged (22), and dual $\mathrm{pH}$ probe recording demonstrates different patterns of acid exposure at a given level of the esophagus at a given moment in time (23).

In order to address the effect of acid in $\mathrm{BE}$ we first investigated whether exposure of $\mathrm{BE}$ to acid directly affects cell proliferation and differentiation. Secondly, we investigated whether there is a relationship between the pattern of acid exposure and the heterogeneity of this complex epithelium. These questions were addressed using an ex vivo approach in which endoscopic biopsies were cultured in an organ culture system. The $\mathrm{pH}$ of the media was acidified either continuously, or for a 1-h 
pulse followed by 24-h culture at $\mathrm{pH}$ 7.4. At specified time points, cell differentiation was assessed ultrastructurally and by measuring villin expression; cell proliferation was examined using tritiated thymidine incorporation or proliferating cell nuclear antigen expression (PCNA).

The cytoskeletal protein villin was selected as a marker of cell differentiation because of its restricted localization to the microvillus $(24,25,26)$. Villin is one of the first cytoskeletal proteins to be localized to the apical membrane in development (27), it is important for microvillus assembly (28-31), and consequently villin has been widely used as a marker of epithelial cell differentiation $(26,32)$. In addition we have previously demonstrated that villin expression in BE tightly correlated with the presence of microvilli (18).

Here, we demonstrate that acid variably influences cell differentiation and proliferation in $\mathrm{BE}$, depending on the pattern of exposure to low $\mathrm{pH}$. Based on our findings, we propose a model in which the diverse patterns of acid exposure in vivo may lead to variable differentiation and proliferation phenotypes within BE. As a consequence, the dynamic effect of acid may contribute to the observed heterogeneity and unpredictable progression to dysplasia seen in $\mathrm{BE}$.

\section{Methods}

Patient and tissue collection. Endoscopic mucosal samples from esophagus, BE, and duodenum were obtained from patients with previously documented BE undergoing endoscopy for cancer surveillance at the Palo Alto Veterans Affairs Medical Center and Stanford University Hospital. Biopsies were collected under a protocol that was approved by the Medical Committee for the Protection of Human Subjects. All mucosal samples were divided into two parts using a razor blade. One part was formalin fixed and subsequently analyzed microscopically by an independent histopathologist, and the second part was placed immediately in supplemented medium (see below) and used for the experiments described.

Organ culture. Organ culture was performed essentially as described (33). Briefly, mucosal biopsies were cut in half using aseptic technique and randomly assigned to acid or control groups in order to avoid sampling bias. The biopsies were placed on a sterilized stainless steel grid within a $35-\mathrm{mm}$ Petri dish so that culture medium $(3 \mathrm{ml})$ just covered the surface of the biopsy. The Petri dishes were placed on racks in a sterile sealed jar (Torsion Balance Company, Clifton, NJ) and perfused with $95 \% \mathrm{O} 2,5 \% \mathrm{CO}_{2}$, and then cultured at $37^{\circ} \mathrm{C}$. The jar was gassed before incubation and regassed each time it was opened. For all experiments, we used Medium 199 supplemented with $10 \%$ heat-inactivated fetal calf serum, $1 \mu \mathrm{g} / \mathrm{ml}$ of insulin (34), streptomycin $(500 \mathrm{U} / \mathrm{ml})$, and penicillin $250 \mathrm{U} / \mathrm{ml}$. For acidic culture conditions, the medium was acidified with $0.1 \mathrm{M} \mathrm{HCl}(\sim 20 \% \mathrm{vol} / \mathrm{vol})$ to achieve the desired $\mathrm{pH}$ then filtered using a $0.45-\mu \mathrm{m}$ Millipore filter. In all experiments, a volume of distilled water $(\sim 20 \% \mathrm{vol} / \mathrm{vol})$ was added to the control nonacidified media to achieve an osmolality equal to that of the acid-treated media ( $300 \mathrm{mosmol} / \mathrm{kg}$ ). In order to confirm tissue viability after organ culture, lactate dehydrogenase (LDH) assays were performed (35) using an aliquot of tissue culture medium taken at the end of the culture period and an LDH assay kit (Sigma Chemical Company, St. Louis, MO). Biopsy samples homogenized in media with Triton X-100 and then sonicated, before measuring the $\mathrm{LDH}$ of the media, were used as positive controls. Control tissues were processed at the same $\mathrm{pH}$ as the experimental samples to adjust for $\mathrm{pH}$ sensitivity of the assay. The absorbance values (at $490 \mathrm{~nm}$ ) were expressed as a percentage of the positive control, and adjusted for protein content of the biopsy.

Antibodies. A rabbit anti-chicken villin antibody, provided by $\mathrm{P}$. Matsudaira (Whitehead Institute for Biological Research, Massachu- setts Institute of Technology, Cambridge, MA), was used as described (18). Mouse anti-moesin was obtained from H. Furthmayr (Department of Pathology, Laboratory of Experimental Oncology, Stanford University School of Medicine, Stanford, CA). Peroxidase labeled goat anti-rabbit and anti-mouse IgG; and mouse anti-PCNA were all purchased from Sigma Chemical Company and used as recommended by the supplier.

Protein extraction and immunoblot analysis. Tissues were homogenized $\left(4^{\circ} \mathrm{C}\right)$ in $1 \%$ deoxycholate, $1 \%$ Nonidet P- $40,0.1 \%$ sodium dodecylsulfate in $\mathrm{pH} 7.4$ PBS containing $5 \mathrm{mM}$ EDTA, $15 \mu \mathrm{g} /$ $\mathrm{ml}$ aprotinin, $10 \mu \mathrm{M}$ leupeptin, $10 \mu \mathrm{M}$ pepstatin, and $0.1 \mathrm{mM}$ phenylmethylsulfonyl fluoride (collectively termed DNS buffer). The protease inhibitors were added just before solubilization, and homogenization was done using Kontes glass tissue grinders. Lysates were centrifuged at $6,000 \mathrm{~g}\left(20 \mathrm{~min}\right.$ at $\left.4^{\circ} \mathrm{C}\right)$ and protein concentrations were measured by the BCA protein assay as recommended by the manufacturer (Pierce Chemical Co., Rockford, IL). Proteins were separated using $10 \%$ SDS-polyacrylamide gel electrophoresis then transferred to nitrocellulose membranes $(0.45 \mu \mathrm{m}$; Schleicher \& Schuell Inc., Keene, NH) in transfer buffer containing $12.5 \mathrm{mM}$ Tris$\mathrm{HCl}(\mathrm{pH} 8.3), 100 \mathrm{mM}$ glycine, and $20 \%$ methanol $\left(40 \mathrm{~V}, 12 \mathrm{~h}, 4^{\circ} \mathrm{C}\right)$. Following transfer, membranes were blocked for $2 \mathrm{~h}$ in MT buffer ( $5 \%$ dry non-fat milk in PBS containing $0.2 \%$ Tween 20 ), then for $1 \mathrm{~h}$ $\left(22^{\circ} \mathrm{C}\right)$ in primary antibody $(1: 5000$ dilution for anti-villin, and 1:1000 dilution for anti-moesin). Membranes were washed in MT buffer and then incubated with peroxidase-conjugated secondary antibody $(1: 1,000$ dilution) for $1 \mathrm{~h}$ at $22^{\circ} \mathrm{C}$. After washing in MT buffer for $1 \mathrm{~h}$, bands were visualized using an enhanced chemiluminescence system (Amersham Corporation, Amersham, UK). Villin expression was generally all or none and therefore was scored as $0=$ non detectable, $1=$ present.

Histopathology and electron microscopy. Paraffin embedded sections of the endoscopic biopsies were independently analyzed by a pathologist unaware of the molecular findings. Standard histopathologic classifications were used to confirm the presence of $\mathrm{BE}$ and to assess the degree of dysplasia $(36,37)$. Only BE biopsy specimens with incomplete intestinal metaplasia, as defined by a specialized (intestinalized) surface and pit epithelium with goblet cells on hematoxylin/eosin and Alcian blue stains, were included in the study (38). For histopathological examination after organ culture, paraffin embedded sections were prepared and stained with hematoxylin and eosin according to a standard protocol. For electron microscopy, biopsies were oriented with their mucosal side up, and then fixed using $2 \%$ glutaraldehyde in PBS $\left(30 \mathrm{~min}, 4^{\circ} \mathrm{C}\right)$. After rinsing, tissues were postfixed in $1 \% \mathrm{OsO}_{4}\left(4^{\circ} \mathrm{C}, 45 \mathrm{~min}\right)$, rinsed, dehydrated, and embedded in Epon. Ultrathin sections were cut, collected on grids, and then stained with $1 \%$ uranyl acetate and lead citrate before examination (18). In order to quantitate the number of microvilli in acid treated versus non-acid-treated sections of $\mathrm{BE}$, three grids were examined from each group. The person performing the analysis, (RCF), was unaware of which experimental group the grid being examined represented. Eight microscopic fields $(\times 7,100)$ were counted from each grid, from which the mean \pm SE was generated for statistical analysis.

Immunohistochemistry. Tissue sections were deparaffinized, and then rehydrated with PBS ( $\mathrm{pH}$ 7.2). For staining with PCNA, sections were incubated with 1:100 monoclonal anti-PCNA (Sigma) for $1 \mathrm{~h}$ $\left(22^{\circ} \mathrm{C}\right)$. After washing, peroxidase-conjugated goat anti-mouse $\mathrm{IgG}$ (1:100) was added and visualization was performed using the 3,3'diaminobenzidine method (Vector Laboratories Inc, Burlingame, CA). Sections were counterstained lightly with hematoxylin. Photographs were taken using Ektachrome Kodak Elite 400 color slide film, which was then scanned to generate prints.

Scoring of PCNA immunolocalization. PCNA labeling of BE sections was assessed in two zones: the lumenal surface and the gland cells as previously described (39). At least 50 surface cells were counted from each of three representative areas for each patient; and similarly, at least six glands in each biopsy section were assessed. Only well defined nuclear staining was counted as positive, and a 
mean score of the percentage of positive cells was generated from the patients studied.

Cell proliferation assays. All endoscopic biopsies were weighed and then processed immediately for organ culture. Using an organ culture system as described above, $1 \mu \mathrm{Ci} / \mathrm{ml}\left[{ }^{3} \mathrm{H}\right]$ thymidine (DupontNew England Nuclear, Wilmington, DE) was added to the culture medium followed by 6,12 or $24 \mathrm{~h}$ incubations. For the acid-pulse experiments, $\left[{ }^{3} \mathrm{H}\right]$ thymidine was added to the culture media with or without acid for the 1-h pulse. Fresh media $(\mathrm{pH} 7.4)$ and $\left[{ }^{3} \mathrm{H}\right]$ thymidine were then added for an additional $24 \mathrm{~h}$. At the end of the incubation, the explants were lifted from the grid and rinsed thoroughly with unlabeled culture media to remove unincorporated radioactivity. The tissue sections were then homogenized, passed through a $19-\mathrm{G}$ needle, and processed using a cell harvester (Skatron, Tranby, Norway). The incorporated radioactivity was measured and expressed as cpm/ mg tissue (40).

Statistical analysis. Statistical evaluation was performed on a Macintosh computer using the Student's paired $t$-test and two-tailed $t$-test (41) and a Microsoft Excel software package. All results were expressed as the mean $\pm \mathrm{SE}$ and were representative of pooled data from at least three patients in each group.

\section{Results}

Villin expression in BE is increased after culture in continuous acid. In order to determine the effect of $\mathrm{pH}$ on cell differentiation, we performed organ culture experiments in media that was titrated to a $\mathrm{pH}$ range of 1-12, and then assessed villin expression as a marker of intestinal cell differentiation. After $24 \mathrm{~h}$ of explant culture, induction of villin expression was noted in $\mathrm{BE}$ samples incubated at a $\mathrm{pH}$ range of 3-5, and found to be maximal at pH 3.5 (Fig. 1). Villin expression was not detected in $\mathrm{BE}$ explants grown at $\mathrm{pH}<2.5$ (data not shown). In contrast, villin expression in the duodenum was reduced at $\mathrm{pH}$ extremes (i.e., $<5$ or $>9$ ) (Fig. 1, compare lanes 5, 7 with lanes 3,9 and 11). The observed increase in villin expression upon exposure of $\mathrm{BE}$ explants to acid is specific, in that it was not observed in moesin (Fig. 1) which is another microvillus pro-

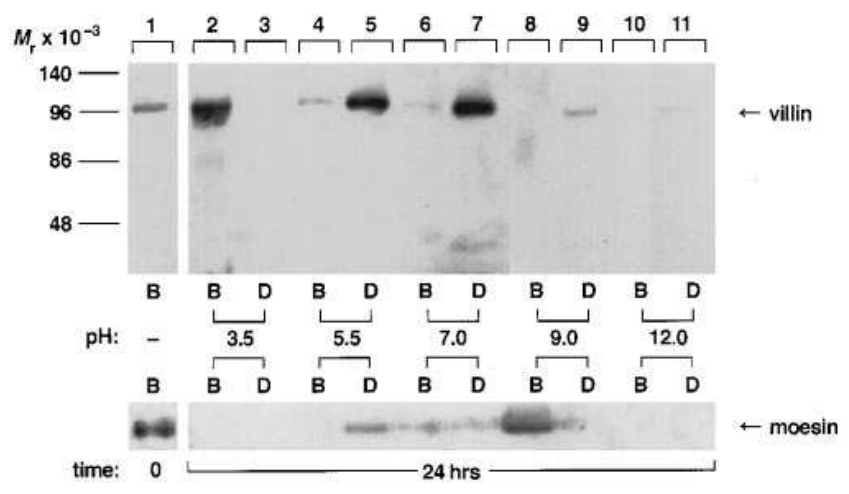

Figure 1. Effect of $\mathrm{pH}$ on villin expression in $\mathrm{BE}$ and duodenal biopsies. Endoscopic biopsies were cultured using an organ culture system at various $\mathrm{pH}$ levels for $24 \mathrm{~h}$ (as described in Methods). After culture, using $25 \mu \mathrm{g}$ of protein per lane, immunoblotting was performed using anti-villin and anti-moesin antibodies. This representative immunoblot (1 patient out of 3 ) demonstrates increased villin expression at acidic $\mathrm{pH}$ (top) in Barrett's esophagus $(B)$ compared with duodenum $(D)$. Moesin expression, used as a control, in the same patient biopsies (bottom) demonstrates the specificity of the increase of villin expression in $\mathrm{BE}$ at acidic $\mathrm{pH}$. tein (42). As shown in Fig. 1, moesin expression was reduced in both $\mathrm{BE}$ and duodenum at $\mathrm{pH}$ extremes (i.e., $5>\mathrm{pH}>9$ ).

Given that villin expression in $\mathrm{BE}$ was maximal at $\mathrm{pH} 3.5$, organ culture experiments comparing pH 7.4 with pH 3.5 culture conditions were performed for a series of biopsies from 12 patients over a 6 - and $24-\mathrm{h}$ time period. The cumulative data from these patients (Fig. $2 A$ ) demonstrated that before culture $25 \%$ of BE samples express villin, similar to our previous results (18). After exposure to acid ( $\mathrm{pH} 3.5$ ), villin expression increased to $50 \%$ and $82 \%$ of BE samples after 6 and 24 culture h, respectively $(P<0.05)$ (Fig. $2 A)$. In contrast, villin expression in the control group (i.e., $\mathrm{pH} 7.4$ ) did not change significantly over $24 \mathrm{~h}$ (Fig. $2 \mathrm{~A}$ ). As expected, $100 \%$ of duodenal samples expressed villin at time 0 , and there was no significant change in villin expression over $24 \mathrm{~h}$ at $\mathrm{pH} 7.4$ (Fig. 2 B). However, $6 \mathrm{~h}$ or $24 \mathrm{~h}$ culture of duodenal biopsies in acid media $(\mathrm{pH} 3.5)$ resulted in significant reduction of villin expression

\section{A. Barrett's}

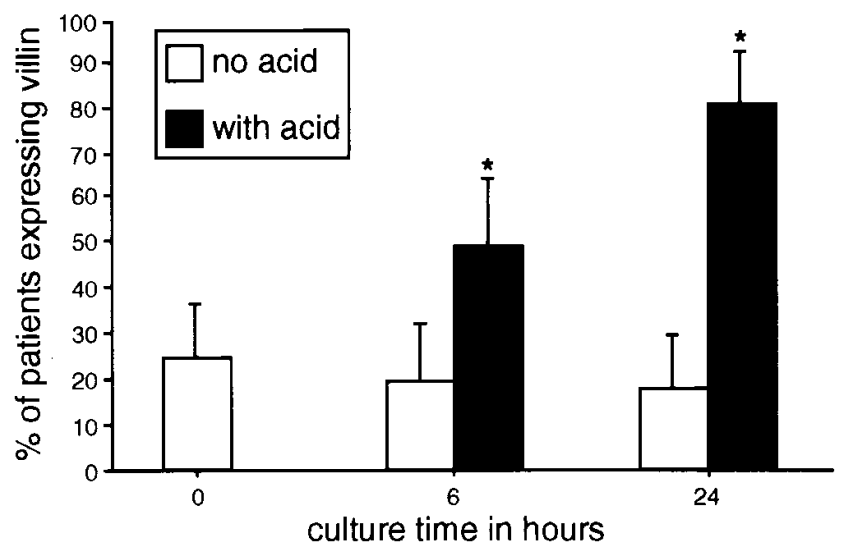

\section{B. Duodenum}

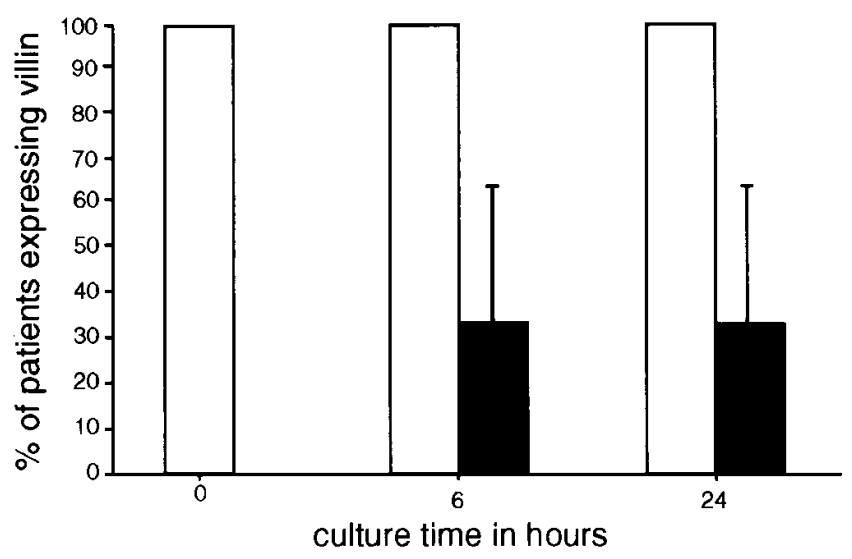

Figure 2. Cumulative results of villin expression, assessed by immunoblotting, in BE and duodenal biopsies cultured for up to $24 \mathrm{~h}$ with no acid ( $\mathrm{pH} 7.4)$ vs. acid ( $\mathrm{pH} 3.5)$ in an organ culture system. $(A) \mathrm{Cu}-$ mulative data from BE (12 patients). ( $B$ ) Data from duodenum (3 patients). Both panels show percentage patients ( \pm 1 SEM) expressing villin. $* P<0.05$ for comparison between acid-treated and non acidtreated samples at the same time point. 
A

no acid

acid

esophagus
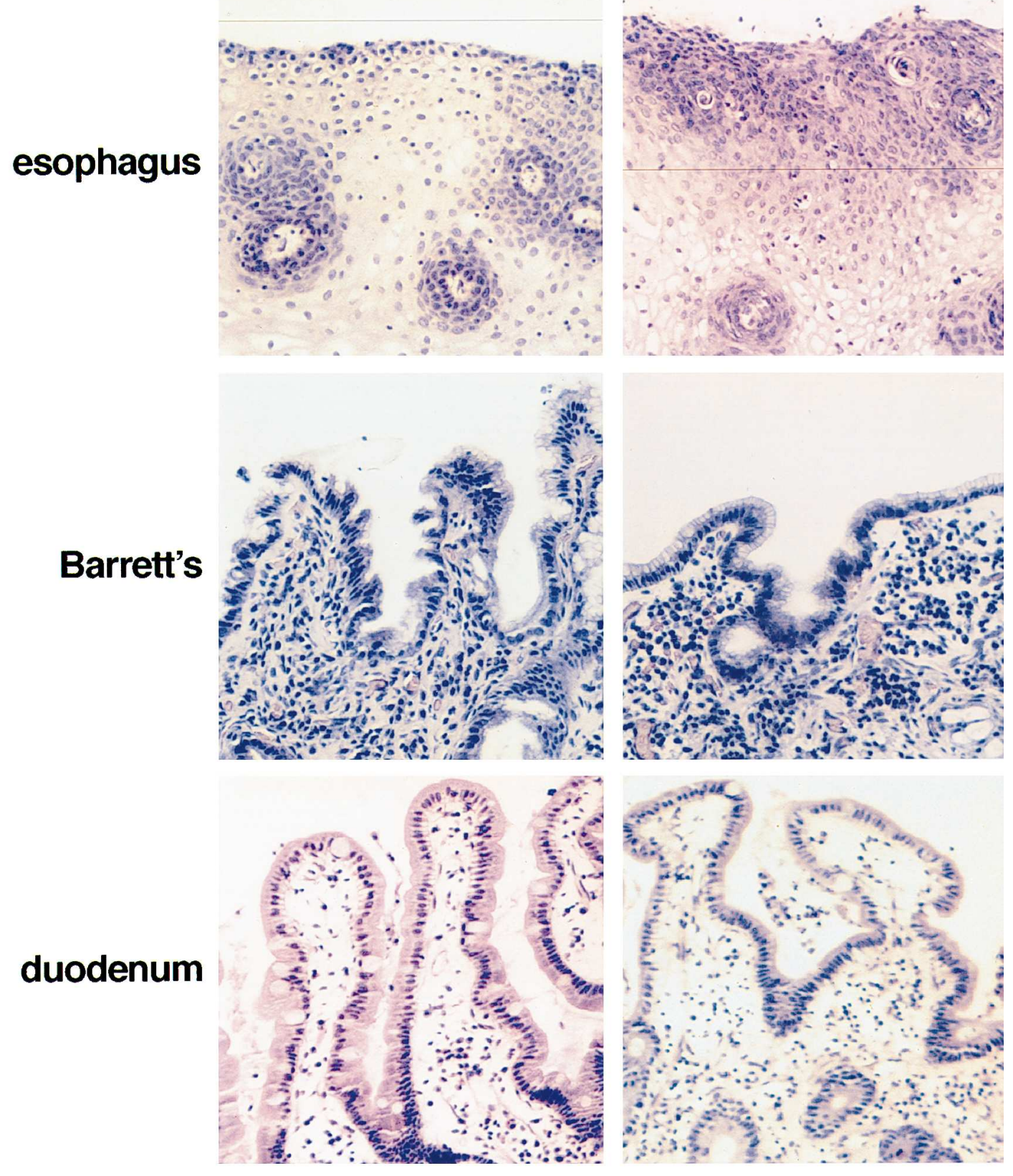

B

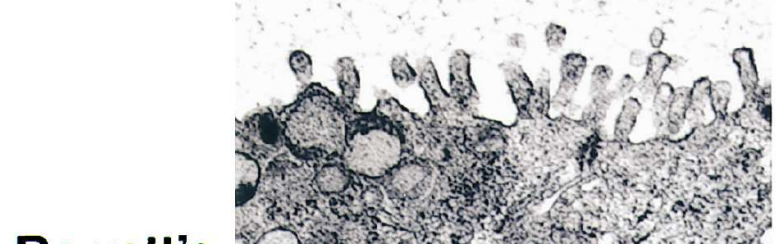

Barrett's
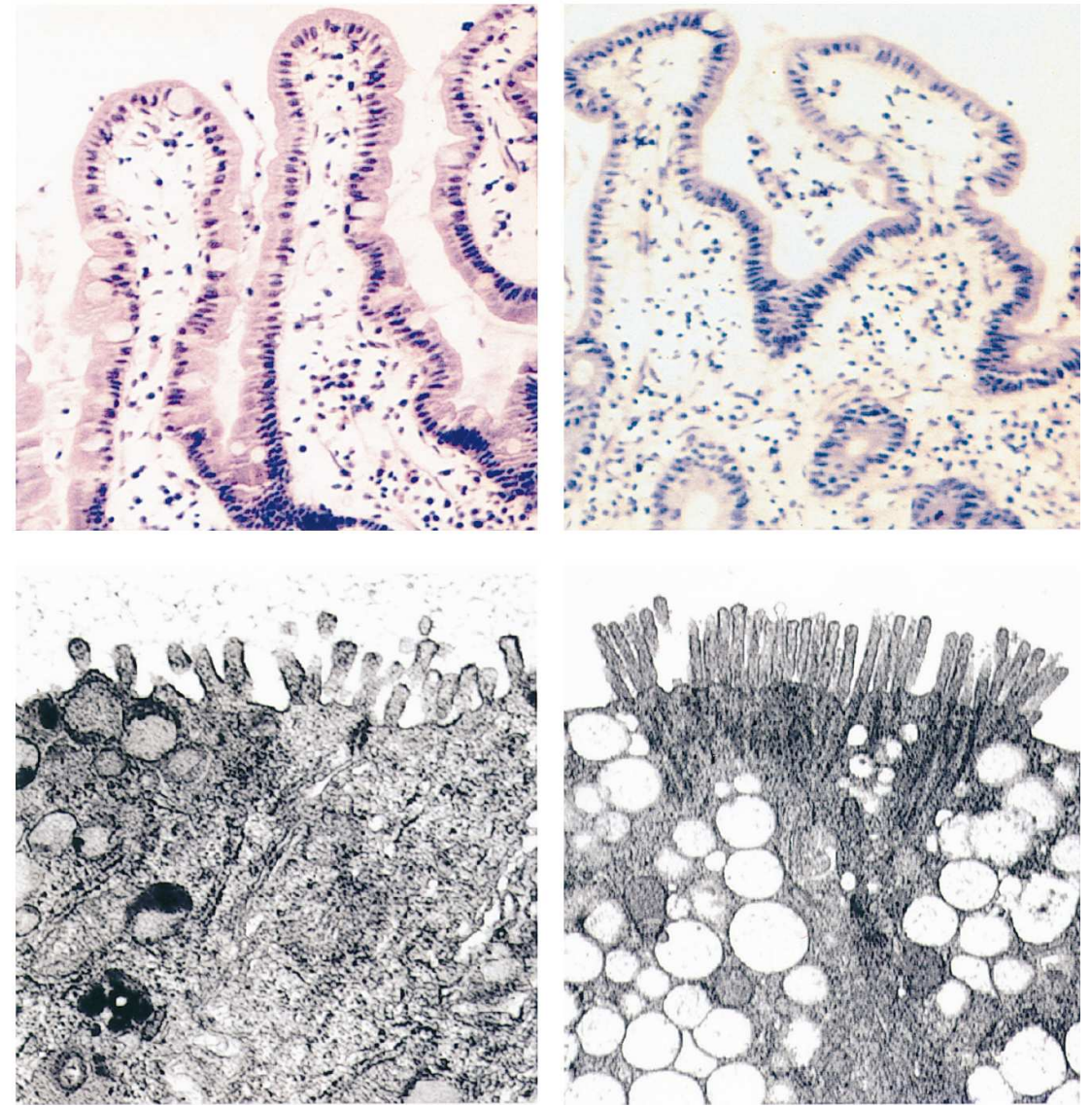
(Fig. 2 B). As expected, normal esophagus did not express villin under any of the conditions studied and moesin expression of duodenal cultures was not significantly altered under similar conditions (not shown).

Tissue viability is maintained in organ culture. In order to assess tissue viability after organ culture and $\mathrm{pH}$ manipulation of the media, lactate dehydrogenase (LDH) release and tissue integrity as determined by light microscopy were examined. For all samples, the results showed that there was no significant LDH release compared to the Triton $\mathrm{X}$ extracted, positive controls (normal esophagus, $\mathrm{BE}$ and duodenum explants from a representative patient cultured at $\mathrm{pH} 3.5$, and 7.4, released $<7.2 \%$ LDH compared with the positive control, data not shown). Light microscopy of hematoxylin and eosin stained sections (Fig. $3 A$ ) revealed that tissue architecture was well maintained for all tissues cultured in neutral or acidic $(\mathrm{pH}$ 3.5) conditions. There was some surface debris, blunting of villi and interstitial edema with decreased cellularity of the lamina propria seen in the duodenal samples (Fig. 3) after culture at low $\mathrm{pH}$. These findings have been observed after intestinal organ culture even without manipulation of the media $\mathrm{pH}$, and the tissue has been shown to be viable by BrdU incorporation and protein synthesis (43).

Villin expression in acid-treated BE is correlated with maturation of the brush border. In order to further confirm tissue viability and assess whether the increase in villin expression in acid-treated BE correlates with microvilli formation, we compared acid-treated and non-acid-treated BE samples $(n=3$ in each group), at the ultrastructural level. Our results demonstrated that there were significantly more microvilli after culture at $\mathrm{pH} 3.5$, compared with $\mathrm{pH}$ 7.4. There were 12.9 \pm 1.09 microvilli (mean $\pm \mathrm{SE}$ ) in the acid treated group, compared with $5.25 \pm 0.62$ microvilli in the non-acid-treated group $(P<$ $0.001)$. Furthermore, the brush border appeared more mature in the acid-treated group with long, fairly uniform microvilli on the apical surface (Fig. $3 \mathrm{~B}$ ). Multiple non-electron dense intracellular vacuoles were also noted in the acid-treated sections. These were in contrast to the stippled or homogeneous mucous granules seen in mucous, pseudoabsorptive and goblet cells in the non-acid-treated tissues. The identity of these vacuoles is unclear but may represent granules that have released their mucin in response to acid exposure (17).

The effect of acid on cell proliferation is dynamic. We then used $\left[{ }^{3} \mathrm{H}\right]$ thymidine incorporation and PCNA expression to examine cell proliferation in response to either continuous acid exposure or a short acid-pulse ( $\mathrm{pH}$ 3.5). As shown in Fig. $4(A-C)$ tritiated thymidine uptake was greatest in the $\mathrm{BE}$ samples, under all $\mathrm{pH}$ conditions, as compared with esophagus and duodenum $(P<0.05)$. This is in accordance with previous studies $(39,44,45)$ which have demonstrated that at $\mathrm{pH} 7.4 \mathrm{BE}$ has a higher proliferative index ex vivo than squamous esophageal epithelium for example. In contrast, continuous acid exposure reduced cell proliferation in all tissue types, although $\mathrm{BE}$ continued to proliferate slightly faster than duodenal or esophageal biopsies (Fig. $4 \mathrm{C}$ ). The unique finding, however, was that after a short period of acid exposure $(1 \mathrm{~h})$, followed by restitution to neutral $\mathrm{pH}, \mathrm{BE}$ tissue proliferated roughly sixfold faster than either normal esophagus or duodenum $(P<$ 0.01 , Fig. $4 B$ ). Furthermore, acid-pulsed BE proliferated faster than $\mathrm{BE}$ tissue cultured continuously at $\mathrm{pH} 7.4$ over a 24-h period $(P<0.05$, Fig. $4 D)$. In contrast proliferation of duodenal samples was reduced regardless of the duration of the acid exposure (Fig. $4 \mathrm{~B}, \mathrm{C}$ ). The hyperproliferative response of BE after an acid pulse is highlighted in Fig. $4 D$, which combines proliferation data from Fig. $4 A-C$ for all the culture conditions examined in BE.

Since $\left[{ }^{3} \mathrm{H}\right]$ thymidine incorporation is a measure of total DNA synthesis and does not discriminate between cellular compartments, we examined the specific cell populations of $\mathrm{BE}$ that manifested increased proliferation by PCNA staining (46) after organ culture for $24 \mathrm{~h}$ in continuous acid, pulsed acid, or $\mathrm{pH}$ 7.4. A marked cell proliferation difference was noted between continuous acid versus acid-pulsed BE cultures, similar to that observed in the thymidine incorporation experiments (Fig. 5). Specifically, PCNA staining was seen in a mean of $10 \%$ of gland cells at $\mathrm{pH} 7.4$ (control) which decreased to a mean of $4 \%$ of gland cells after chronic acid exposure (Fig. $5 A$ ). In contrast, after a short acid-pulse PCNA staining increased dramatically to $35 \%(P<0.05)$ in $\mathrm{BE}$ glands compared to $\mathrm{pH} 7.4$, and also increased to $12 \%$ of surface cells $(P<0.05$ compared to surface cells at $\mathrm{pH} 7.4)$ (Fig. $5 A$ ).

\section{Discussion}

Our ex vivo experiments demonstrate for the first time that acid affects cell proliferation and differentiation in $\mathrm{BE}$, and that such an effect is dynamic depending on the pattern of acid exposure. Continuous acid exposure results in increased villin expression and reduced cell proliferation, thereby suggesting a differentiated phenotype. In contrast, after a short acid-pulse proliferation is dramatically increased suggesting a relatively undifferentiated phenotype. These findings may be significant in terms of the heterogeneity and the variable risk of neoplastic progression within an area of BE.

Significance of an acid-induced increase in villin expression in $B E$. We previously showed that, before organ culture, the highly heterogeneous Barrett's epithelium expresses easily detectable villin in $\sim 35 \%$ of randomly obtained endoscopic biopsies from BE patients (18). In the 12 new patients that we studied here, villin expression was noted in $25 \%$ of the patients (Fig. 2) and induction of villin expression in BE in response to acid was shown to be greatest after $24 \mathrm{~h}$ of culture at a $\mathrm{pH}$ of 3.5 (Fig. 1, longer culture periods were not studied). The relatively short time frame within which acid-induced villin expression increased in $\mathrm{BE}$, is not surprising in view of in vivo pulse labeling experiments that have shown that villin turnover within the brush border occurs with a half-life of about $6 \mathrm{~h}$

Figure 3. Morphological changes of BE and duodenum biopsy specimens after $24 \mathrm{~h}$ of organ culture at $\mathrm{pH} 7.4$ (no acid) or pH 3.5 (acid). Following organ culture samples for histopathology were placed immediately in formalin, then sectioned and stained with hematoxylin and eosin (see Methods). The top 3 panels $(A)$ are stained sections $(20 \times)$ of normal esophagus, Barrett's esophagus and duodenum after $24 \mathrm{~h}$ culture with no acid vs. acid; in which tissue integrity is shown to be intact. $(B)$ The corresponding electron micrograph $(\times 7,000)$ appearance of $\mathrm{BE}$ after $24 \mathrm{~h}$ culture with or without acid. A more mature brush border is seen in the acid-treated tissue. 
A

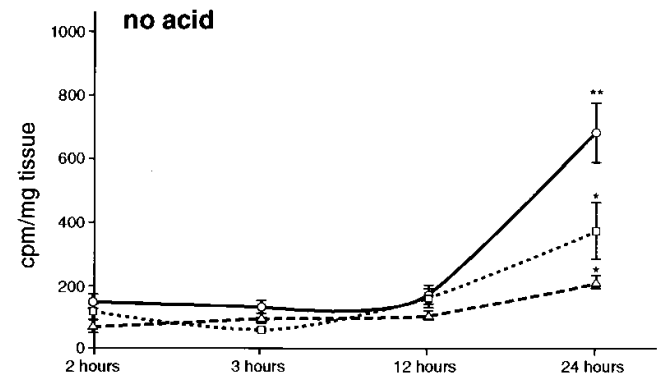

B

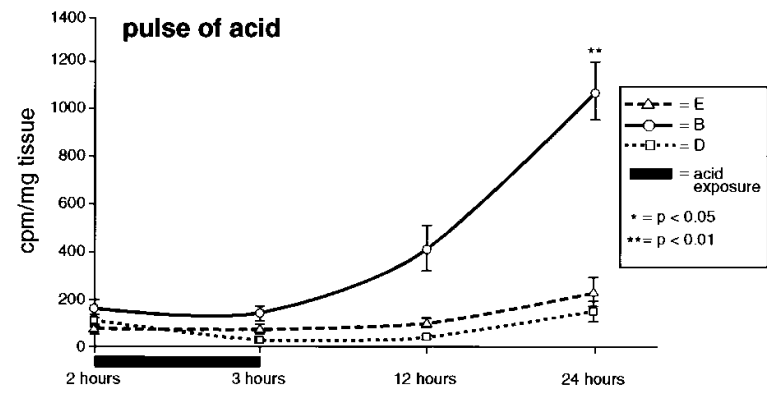

C

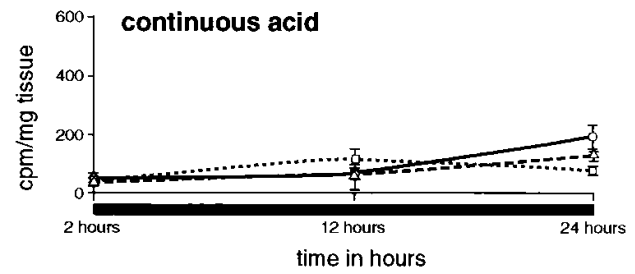

D

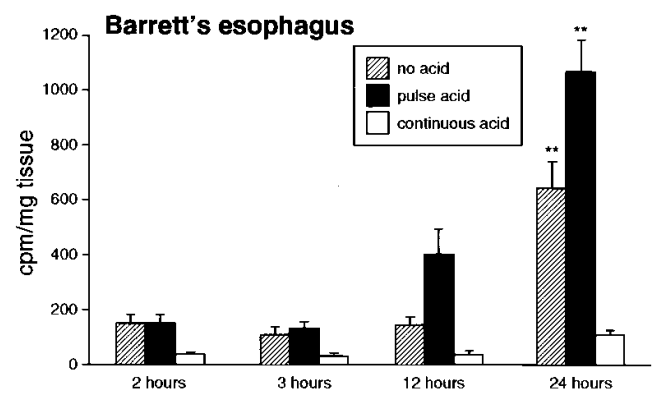

Figure 4. Cell proliferation under different $\mathrm{pH}$ conditions. Endoscopic biopsies of normal esophagus $(E)$, Barrett's esophagus $(B)$ and duodenum $(D)$ were weighed, and then cultured in the presence of tritiated thymidine $(1 \mu \mathrm{Ci} / \mathrm{ml})$ with either no acid $(\mathrm{pH} 7.4),(A, n=8)$, for a 1 hour acid-pulse $(\mathrm{pH} 3.5)$ followed by $\mathrm{pH} 7.4,(B, n=4)$, or with continuous acid (pH 3.5), $(C, n=4)$. At 2, 3, 12, and $24 \mathrm{~h}$ time points samples were washed and homogenized, the DNA extracted using a cell harvester, and tritiated thymidine incorporation into DNA assessed by a scintillation counter (see Methods). Each graph demonstrates $\mathrm{cpm} / \mathrm{mg}$ tissue after the various culture periods. BE proliferates more than $E$ and $D$ under all conditions, but particularly after an acid-pulse. $(D)$ Combines the data for BE only, from $(A),(B)$ and $(C)$, to emphasize the augmented cell proliferation after an acid-pulse in this tissue. ${ }^{*} P$ values are time 2 compared with $24 \mathrm{~h}$, and also apply to proliferation after a pulse of acid compared to no acid at $24 \mathrm{~h}$.

(47). A possible bias in our study is the intrinsically patchy expression of villin in $\mathrm{BE}$ and hence a difficulty in demonstrating a real change in villin expression. However, with a patient sample size of 12 , we feel that the dramatic increase in villin ex- pression as a result of continuous acid exposure is unlikely to result purely from a sampling bias. In addition we observed a similar dramatic induction of villin expression in several epithelial cultured cell lines (not shown).

Villin expression per se does not result in a brush border unless the protein expression reaches a critical level. For example, it has been shown previously that in the course of enterocytic migration and differentiation from the crypt towards the villus, the amount of villin dramatically increases and is concurrent with the appearance of brush border microvilli (48, 49). Furthermore, transfection experiments have indicated that high levels of villin expression are required before numerous, long microvillar structures are seen $(30,50)$. In this study we demonstrated that the unique induction of villin expression in response to acid does reach a level sufficient to be correlated with the existence of a fairly mature brush border (Fig. 3 $B$ ). In contrast, villin expression in the duodenum is reduced after acid exposure (Figs. $1 A$ and $2 B$ ), which is in accordance with the observation that the small intestinal brush border is lost after exposure to acetic acid (51). This may in part be attributed to the loss of the unstirred mucous layer and substantial secretion of bicarbonate ions in an ex vivo system. For example, the duodenum in contrast to the esophageal epithelium depends upon these protective mechanisms in order to maintain an intracellular $\mathrm{pH}$ balance (52).

The functional significance of microvilli formation, other than increasing the surface area (53), is unclear. The only other physiological situation in which microvilli are induced in response to acid is in $\mathrm{H}^{+}$-secreting parietal cells $(54,55)$. The mechanism for the formation of these microvilli is debated, but there is evidence that as a result of lumenal $\mathrm{HCl}$ and the activation of ion transport, there may be osmotic swelling and hence changes in the cytoskeleton (56). It is conceivable that there may be a similar mechanism for microvilli formation in BE. Additional similarity between the findings of this study and the gastric epithelium, comes from indirect evidence which suggests that acid may be important in cell differentiation and proliferation in the stomach. For example, subcutaneous administration of omeprazole to infant rats at a dose sufficient to cause achlorhydria, increased cell proliferation and decreased cell differentiation (57). The altered cell differentiation was characterized by a reduction in mature pepsinogenproducing cells and a delay in the expression of cathepsin, both markers of terminal differentiation in gastric mucosa (57).

The hyperproliferative response of $B E$ to an acid pulse. With regard to cell proliferation markers, $\left[{ }^{3} \mathrm{H}\right]$ thymidine uptake and PCNA expression were evaluated. Although $\left[{ }^{3} \mathrm{H}\right]$ thymidine uptake during the S-phase of the cell cycle is a sensitive method for evaluating cell proliferation, it does not differentiate between different cellular types as found in a complex biopsy explant (58). For this reason PCNA expression was also analyzed immunohistochemically. To that end several studies previously demonstrated that PCNA expression is increased in $\mathrm{BE}$ compared with other glandular epithelia not associated with malignancy, such as gastric type Barrett's $(39,59)$. However, the proliferative response of $\mathrm{BE}$ to acid has not been evaluated previously.

Our results support a reciprocal relationship between cell differentiation and proliferation. While continuous acid reduced cell proliferation, cells proliferated at an increased rate after a brief acid-pulse, and in contrast to the effect of continuous acid exposure, this pulse was not correlated with an in- 


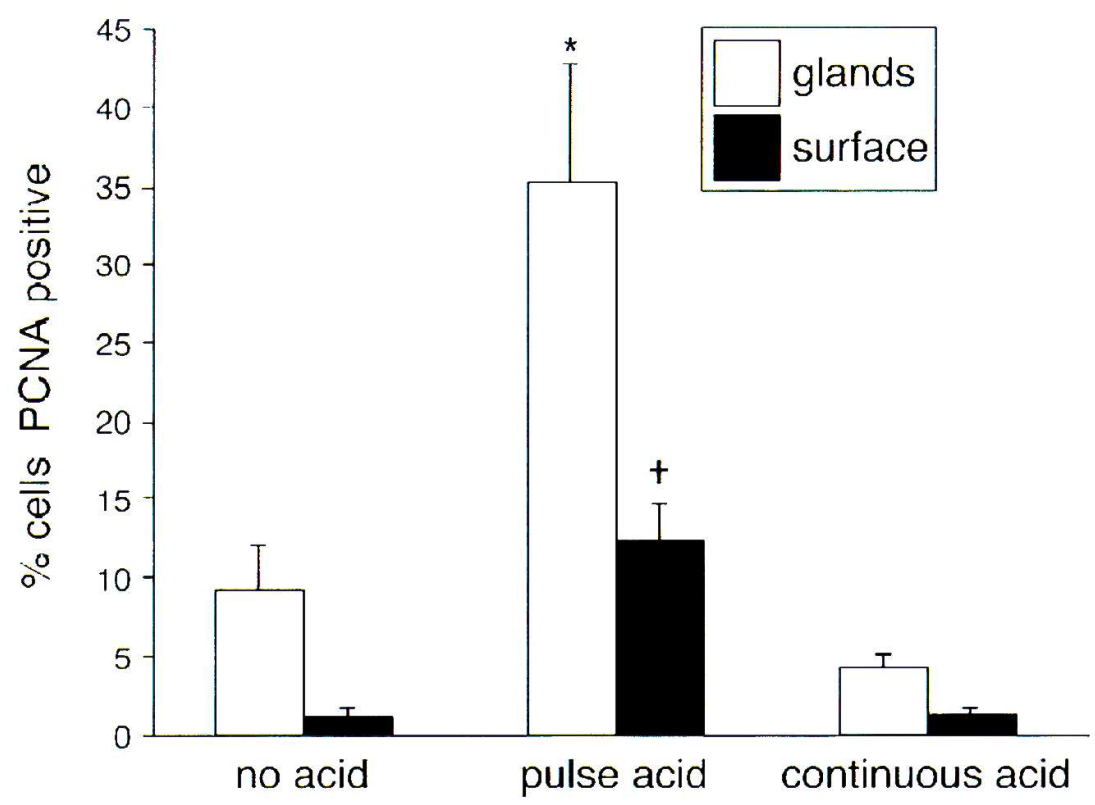

B

\section{a. no acid}

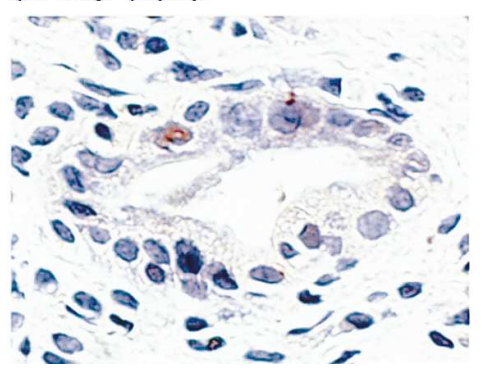

b. pulse acid

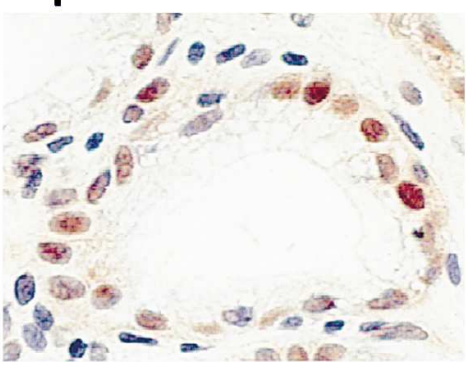

c. continuous acid

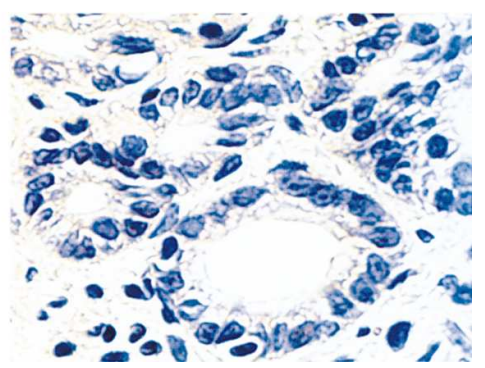

Figure 5. Cell proliferation in glandular and surface cell compartments of $\mathrm{BE}$ under different $\mathrm{pH}$ conditions as determined by proliferating cell nuclear antigen (PCNA) expression. Following $24 \mathrm{~h}$ organ culture with either no acid ( $\mathrm{pH} \mathrm{7.4),} \mathrm{a} 1 \mathrm{~h}$ pulse of acid ( $\mathrm{pH} 3.5)$ followed by $\mathrm{pH} 7.4$, or continuous acid ( $\mathrm{pH} 3.5)$ PCNA expression was assessed by immunohistochemistry using anti-PCNA antibody on paraffin embedded sections (see Methods). A percentage of PCNA-positive nuclei were calculated for gland and surface cells (see Methods). ( $A$ ) demonstrates the $\%$ PCNA-positive cells in the glands and at the surface for the three culture conditions. BE cells proliferate most after an acid-pulse. $* P<0.05$ for gland cells treated with a pulse of acid compared with gland cells cultured with no acid or continuous acid. ${ }^{+} P<0.05$ for surface cells in a similar comparison. (B) Shows PCNA staining (positive nuclei stain brown) for representative BE glands in each of the three culture conditions.

crease in villin expression as assessed by immunoblotting (data not shown). This result suggests that the acid-pulse induced rapidly proliferating cells of BE may be relatively undifferentiated. We chose a short acid-pulse in order to mimic the physiological effect of short reflux episodes and in light of previous data showing that a 30-min infusion of hydrochloric acid in the normal esophagus of dogs triggered cell proliferation at 16-24 h after the acid-pulse (60). Previous studies have shown that reduced intracellular $\mathrm{pH}$ induces changes in the cell cycle and hence influences cell proliferation. Specifically, extracellular $\mathrm{HCl}$ may lower intracellular $\mathrm{pH}(61,62)$ and hence cause cell cycle arrest at the G0/G1 stage. Cells subsequently become stimulated to enter the $\mathrm{S}$ phase as a result of a small rise in in- tracellular $\mathrm{pH}$ mediated by the $\mathrm{Na} / \mathrm{H}$ exchanger (63). Further, tumorigenic Chinese hamster embryo fibroblast cell lines display a slightly higher basal $\mathrm{pH}$ than their nontumorigenic counterparts (64), suggesting that alterations in intracellular $\mathrm{pH}$ can contribute to the acquisition of altered growth properties. Hence, after an acid-pulse, cells that accumulate at G0/G1 may enter the $\mathrm{S}$ phase in a synchronous fashion.

An in vivo model for the dynamic effect of acid on cell proliferation and differentiation in BE. Extrapolating our data to the situation in vivo, one model that can be envisioned is that variable patterns of acid exposure in BE may contribute to the complex, heterogeneous epithelium seen in BE with a consequent variable risk of neoplastic progression (Fig. 6). As such, 


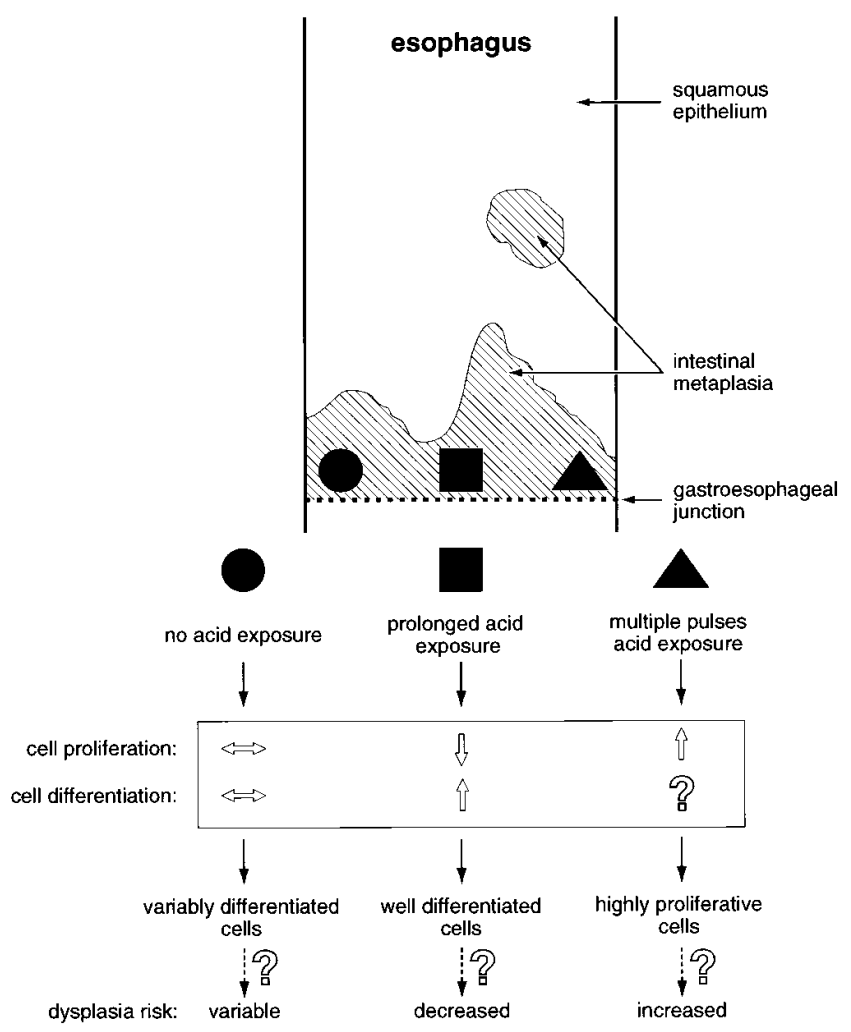

Figure 6. A hypothetical model for the variable effect of acid on Barrett's epithelium in vivo. The effect of prolonged acid exposure (square) and multiple acid-pulses (triangle) on cell proliferation and differentiation are compared to the baseline condition of no acid exposure (circle). The dynamic effects of acid results in a heterogeneous cell population. The potential implications for the dysplasia risk of the resulting cell populations are tentatively suggested.

BE cells pulsed with acid would proliferate preferentially and may in turn have a higher risk of developing dysplasia $(65,66)$. In contrast, cells which have prolonged acid exposure would proliferate slowly, become more differentiated, and hence would be predicted to have a lower likelihood of progressing towards dysplasia. BE cells which are relatively protected from acid would continue their basal proliferating and differentiating states/rates. This model assumes that cells at the same level of the esophagus do indeed have variable degrees of acid exposure as a result of the reflux of gastroduodenal contents. The highly folded tubular structure of the esophagus, with its peristaltic waves provides an ever changing, highly dynamic environment. In support of this, reflux events are influenced by posture (21), have a circadian pattern, vary from day to day (23), and manifest variable dynamics of rapid clearance or persistence (22). Further support comes from studies using dual $\mathrm{pH}$ probes which were placed equidistant from the lower esophageal sphincter. These probes yielded markedly different $\mathrm{pH}$ readings (23), thereby supporting the notion that variations in the pattern of acid exposure do exist within the esophageal mucosa at the same level.

In conclusion, we have demonstrated using an ex vivo $\mathrm{BE}$ culture model that continuous acid exposure induces differentiation and reduces proliferation, while short pulses of acid exposure increase proliferation. Our results raise the possibility that variation in acid exposure may contribute to the molecu- lar and structural heterogeneity seen in BE patients. Additional studies will be needed to examine the mechanism for the hyperproliferative response of $\mathrm{BE}$ to an acid-pulse, and to assess whether the different acid-induced proliferation states play a role in the potential subsequent development of dysplasia and adenocarcinoma. One possible therapeutic implication of our proposed model is that acid suppressive therapy needs to be powerful and continuous enough to completely abolish any acid-pulses and effectively inhibit cell proliferation thus allowing for a more differentiated state in BE epithelia. Such an implication could be tested by comparing the levels of heterogeneity in villin expression in BE patients who are under complete acid suppression, using acid pump inhibitors, with patients who are not completely acid suppressed. It is, however, important to emphasize that other components of gastroduodenal refluxate, such as bile salts or other gastric juice contents, need to be evaluated in terms of their potentially confounding effects.

\section{Acknowledgments}

We are very grateful to Paul Matsudaira and Heinz Furthmayr for providing the necessary antibodies. We thank Nafisa Ghori for performing the electron microscopy, Kris Morrow for preparing the figures and Jon Kosek for reviewing the histopathology. R.C. Fitzgerald is a Fellow of the Association for International Cancer research (AICR).

This work was supported by TAP pharmaceuticals (G. Triadafilopoulos), Veterans Administration Career Development and Merit Awards (M.B. Omary) and Digestive Disease Center grant DK38707.

\section{References}

1. Barrett, N.R. 1957. The lower esophagus lined by columnar epithelium. Surgery (St. Louis). 41:881-894.

2. Spechler, S., and R.K. Goyal. 1986. Barrett's esophagus. N. Engl. J. Med. 315:362-371.

3. Reid, B.J. 1991. Barrett's esophagus and esophageal adenocarcinoma. Gastroenterol. Clin. N. Am. 20:817-834.

4. Haggitt, R.C. 1994. Barrett's esophagus, dysplasia, and adenocarcinoma. Hum. Pathol. 25:982-993.

5. Spechler, S.J., and R.J. Goyal. 1996. The columnar-lined esophagus, intestinal metaplasia, and Norman Barrett. Gastroenterology. 110:614-621.

6. Sarr, M.G., S.R. Hamilton, G.C. Marrone, and J.L. Cameron. 1985. Barrett's esophagus: its prevalence and association with adenocarcinoma in patients with symptoms of gastroesophageal reflux. Am. J. Surg. 149:187-193.

7. Blot, W.J., S.S. Devesa, R.W. Kneller, and J.F. Fraumeni, Jr. 1991. Rising incidence of adenocarcinoma of the esophagus and gastric cardia. J. Am. Med. Assoc. 265:1287-1289.

8. Levine, D.S., R.C. Haggitt, P.L. Blount, P.S. Rabinovitch, V.W. Rusch, and B. Reid. 1993. An endoscopic biopsy protocol can differentiate high-grade dysplasia from early adenocarcinoma in Barrett's esophagus. Gastroenterology. 105:40-50.

9. Stein, H.J., S. Hoeft, and T.R. DeMeester. 1992. Reflux and motility pattern in Barrett's esophagus. Dis. Esoph. 5:21-28.

10. Stein, H.J., S. Hoeft, and T.R. DeMeester. 1993. Functional foregut abnormalities in Barrett's esophagus. J. Thorac. Cardiovasc. Surg. 105:107-111.

11. Bremner, R.M., P.F. Crookes, T.R. DeMeester, J.H. Peters, and H.J. Stein. 1992. Concentration of refluxed acid and esophageal mucosal injury. Am. J. Surg. 164:522-527.

12. Seto, Y., and O. Kobori. 1993. Role of reflux oesophagitis and acid in the development of columnar epithelium in the rat oesophagus. Br. J. Surg. 80: 467-470.

13. Hui, Li., T.N. Walsh, G. O’Dowd, P. Gillen, P.J. Byrne, and T.P.J. Hennessy. 1992. Mechanisms of columnar metaplasia and squamous regeneration in experimental Barrett's esophagus. Surgery (St. Louis). 115:176-181.

14. Gore, S., C.J. Healey, R. Sutton, I.A. Eyre-Brook, M.W. Gear, N.A. Shepherd, and S.P. Wilkinson. 1993. Regression of columnar lined (Barrett's) oesophagus with continuous omeprazole therapy. Aliment. Pharmacol. Ther. 7: 623-628.

15. Sampliner, R.E. 1994. Effect of up to 3 years of high-dose lansoprazole on Barrett's esophagus. Am. J. Gastroenterol. 89:1844-1848. 
16. Collen, M.J., J.H. Lewis, and S.B. Benjamin. 1990. Gastric acid hypersecretion in refractory gastroesophageal reflux disease. Gastroenterology. 98:654661.

17. Levine, D.S., C.E. Rubin, B.J. Reid, and R. Haggitt. 1989. Specialized metaplastic columnar epithelium in Barrett's esophagus: a comparative transmission electron microscopic study. Lab. Invest. 60:418-432.

18. Kumble, S., M.B. Omary, L.F. Fajardo, and G. Triadafilopoulos. 1996. Multifocal heterogeneity in villin and Ep-cam expression in Barrett's esophagus. Int. J. Cancer. 66:48-54.

19. Kumble, S., C. Cartwright, B. Omary, and G. Triadafilopoulos. 1996. Upregulation of src in premalignant Barrett's esophagus and esophageal adenocarcinoma. Gastroenterology. 110:A547. In press.

20. Reid, B.J., W.M. Weinstein, K.J. Lewin, R.C. Haggilt, G. Van Deventer, L. Den Besten, and C.E. Rubin. 1988. Endoscopic biopsies diagnose high grade dysplasia or early operable adenocarcinoma without grossly recognizable neoplastic lesions. Gastroenterology. 94:81-90.

21. Shay, S.S., and J.E. Richter. 1996. Origin of atypical reflux symptoms. A case study showing the importance of reflux composition and posture. Dig. Dis. Sci. 41:505-511.

22. DeMeester, T.R., L.F. Johnson, J.I. Guy et al. 1976. Patterns of gastroesophageal reflux in health and disease. Ann. Surg. 184:459-470.

23. Murphy, D.W., Y. Yuan, and D.O. Castell. 1989. Does the intraesophageal $\mathrm{pH}$ probe accurately detect acid reflux? Simultaneous recording with two pH probes in humans. Dig. Dis. Sci. 34:649-656.

24. Matsudaira, P.T., and D.R. Burgess. 1979. Identification and organization of the compartments of the isolated microvillus cytoskeleton. J. Cell Biol. 83:667-673.

25. Bretscher, A., and K. Weber. 1980. Villin is a major protein of microvillus cytoskeleton which binds $\mathrm{G}$ and $\mathrm{F}$ actin in a calcium-dependent manner. Cell. 20:839-847.

26. Mooseker, M.S. 1985. Organization, chemistry and assembly of the cytoskeletal apparatus of the intestinal brush border. Annu. Rev. Cell. Biol. 1:209241.

27. Fath, K.R., and D.R. Burgess. 1995. Not actin alone. Current Biol. 5: $591-593$

28. Shibayama, T., J.M. Carboni, and M.S. Mooseker. 1987. Assembly of the intestinal brush border: appearance and redistribution of microvillar core proteins in developing chick enterocytes. J. Cell Biol. 105:335-344.

29. Bretscher, A., A. Osborn, J. Wehland, and K. Weber. 1981. Villin associates with specific microfilamentous structures as seen by immunofluorescence microscopy on tissue sections and cells microinjected with villin. Exp. Cell. Res. 135:213-219.

30. Friederich, E., C. Huet, M. Arpin, and D. Louvard. 1989. Villin induces microvilli growth and actin redistribution in transfected fibroblasts. Cell. 59: 461-475.

31. De Beauregard, M.C., E. Pringault, S. Robine, and D. Louvard. 1995. Suppression of villin expression by antisense RNA on brush border assembly in polarized epithelial intestinal cells. EMBO (Eur. Mol. Biol. Organ.) J. 14:409421.

32. Pringault, E., M. Arpin, A. Garcia, A. Findori, and D.A. Louvard. 1986. Human villin cDNA clone to investigate the differentiation of intestinal and kidney cells in vivo. EMBO (Eur. Mol. Biol. Organ.) J. 5:3119-3124.

33. Trier, J.S. 1980. Organ culture of the mucosa of human small intestine. Methods Cell Biol. 18:365-384.

34. Lasnitzki, I. 1992. Organ culture. In Animal Cell Culture, a Practical Approach. Freshney R.I. editor, Rickwood D., and Hames B.D., series editors. IRL Press at Oxford University Press, New York, 213-261.

35. Decker, T., and M.L. Lohmann-Matthes. 1988. A quick and simple method for the quantitation of lactate dehydrogenase release in measurements of cellular cytotoxicity and tumour necrosis factor (TNF) activity. J. Immunol. Methods. 15:61-69.

36. Ismail-Beigi, F., and C.E. Pope. 1974. Dysplasia in inflammatory bowel disease. Gastroenterology. 66:1109-1113.

37. Riddell, R.H., et al. 1983. Dysplasia in inflammatory bowel disease: standardized classification with provisional applications. Hum. Pathol. 14:931-968.

38. Rothery, G.A., J.E. Patterson, C.J. Stoddard, and D.W. Day. 1986. Histological and histochemical changes in the columnar-lined (Barrett's) esophagus. Gut. 27:1062-1068.

39. Gray, M.R., P.A. Hall, J. Nash, B. Ansari, P.L. Lane, and A.N. Kingsworth. 1992. Epithelial proliferation in Barrett's esophagus by proliferating cell nuclear antigen immunolocalization. Gastroenterology. 103:1769-1776.

40. Browning, T.H., and J.S. Trier. 1969. Organ culture of mucosal biopsies of human small intestine. J. Clin. Invest. 48:1423-1433.

41. Colton, T. 1974. Statistics in Medicine. Little, Brown and Company, Boston.

42. Lankes, W., and H. Furthmayr. 1991. Moesin: a member of the protein 4.1-talin-ezrin family of proteins. Proc. Natl. Acad. Sci. USA. 88:8297-8301.

43. Howdle, P.D. 1984. Organ culture of gastrointestinal mucosa-a technique for the study of the human gastrointestinal tract. J. Postgrad. Med. 69: 645-652.

44. Pellish, L.P., J.A. Hermos, and G.L. Eastwood. 1980. Cell proliferation in three types of Barrett's epithelium. Gut. 21:26-31.

45. Herbst, J.J., M.M. Berenson, D.W. McCloskey, and W.C. Wiser. 1978. Cell proliferation in esophageal columnar epithelium (Barrett's esophagus). Gastroenterology. 75:683-687.

46. Jankowski, J., and R. Dover. 1993. Cell proliferation, differentiation and cell death in epithelial cells of the esophagus; a critical review of biological markers and their applications to research and diagnosis. Gullet. 3:1-15.

47. Stidwill, R.P., T. Wysolmerski, and D.R. Burgess. 1984. The brush border cytoskeleton is not static: in vivo turnover of proteins. J. Cell Biol. 98:641645 .

48. Robine, S., C. Huet, R. Moll, C. Sahuquillo-Merino, E. Coudrier, A Zweibaum, and D. Louvard. 1985. Can villin be used to identify malignant and undifferentiated normal digestive epithelial cells? Proc. Natl. Acad. Sci. USA. 8: $8488-8492$.

49. Boller, K., M. Arpin, E. Pringault, and H. Reggio. 1988. Differential distribution of villin and villin mRNA in mouse intestinal epithelial cells. Differentiation. 39:51-57.

50. Friederich, E., K. Vancompernolle, C. Huet, M. Goethals, J. Finidon, J. Vandejerckhove, and D. Louvard. 1992. An actin-binding site containing a conserved motif of charged amino acid residues is essential for the morphogenic effect of villin. Cell. 70:81-92.

51. Henle, J. 1837. Symbolae ad anatomia villorum intestinaticum imprimis eorum epithelii et vasorum lacteorum Berolini. M.D. thesis. University of Berlin.

52. Isenberg, J.I., B. Smedors, and C. Johansson. 1985. Effect of graded doses of intraluminal $\mathrm{H}^{+}$, prostaglandin $\mathrm{E}_{2}$, and inhibition of endogenous prostaglandin synthesis on proximal duodenal bicarbonate secretion in unanesthetized rat. Gastroenterology. 88:303-307.

53. Parsons, D.S., 1983. Introductory remarks on the brush border. Ciba Foundation symposium. Pitman Books Ltd, London. 3-11.

54. Forte, J.G., and J.M. Wolosin. 1987. HCl secretion by the gastric oxyntic cell. In Physiology of the Gastrointestinal Tract. Second ed. R. Johnson, editor. Raven Press, New York. 853-865.

55. Forte, J.G and Y. Xuebiao, 1996. The membrane recruitment-andrecycling hypothesis of gastric $\mathrm{HCl}$ secretion. Trends Cell Biol. 6:45-49.

56. Pettit, J.M., I.R. Van Driel, T. Ben-Hock, and P.A. Gleeson. 1996. From coiled tubules to a secretory canaliculus: a model for membrane transformation and acid secretion by gastric parietal cells. Trends Cell Biol. 6:49-53.

57. Kakei, N., M. Ichinose, S. Tsukada, M. Tatematsu, N. Tezuka, C. Furihata, N. Yahagi, M. Matsushima, K. Mikai, K. Kurokawa, et al. 1993. Effects of omeprazole on gastric mucosal growth and differentiation in developing rat Biochem. Biophys. Res. Commun. 197:310-318.

58. Hall, P.A., D.A. Levison, and N.A. Wright. 1992. In Assessment of Cell Proliferation in Clinical Practice. Springer-Verlag, London. pp. 1-23.

59. Gillen, P., M. McDermott, D. Grehan, D. O'B. Hourihane, and T.P.J. Hennessy. 1994. Proliferating cell nuclear antigen in the assessment of Barrett's mucosa. Br. J. Surg. 81:1766-1768.

60. De Backer, A., P. Haentjens, and G. Willems. 1985. Hydrochloric acid a trigger of cell proliferation in the esophagus of dogs. Dig. Dis. Sci. 30:884-890.

61. Hoffman, E.K., and L.O. Simonsen. 1989. Membrane mechanisms in volume and $\mathrm{pH}$ regulation in vertebrate cells. Physiological Rev. 69:315-378.

62. Tobey, N.A., P.R. Srighar, T.O. Keku, E.J. Cragoe, Jr., and R.C. Orlando. 1993. Mechanisms of $\mathrm{HCl}$-induced lowering of intracellular $\mathrm{pH}$ on rabbit esophageal epithelial cells. Gastroenterology. 105:1035-1044.

63. Madshus, I.H. 1988. Regulation of intracellular $\mathrm{pH}$ in eukaryotic cells. Biochem. J. 250:1-8.

64. Ober, S.S., and A.B. Pardee 1987. Intracellular pH is increased after transformation of Chinese hamster embryo fibroblasts. Proc. Natl. Acad. Sci. USA. 84:2766-2770.

65. Farber, E. 1990. Clonal adaptation during carcinogenesis. Biochem. Pharmacology. 39:1837-1846.

66. Wormsley, K.G. 1992. Adaptive mutagenesis-cause of alimentary cancer. Scand. J. Gastroenterol. 193S:68-75. 